NIHON REOROJİ GAKKAISHI Vol. 24, No. 4, 149 156 (1996) 学会筫受賞講演

\title{
Structures and Viscoelastic Properties of Polymer Solutions and Multicomponent-Multiphase Polymer Systems
}

\author{
Ichiro Noda \\ Department of Applied Chemistry, Graduate School of Engineering \\ Nagoya University, Furo-cho, Chikusa-ku, Nagoya 464-01, Japan
}

\begin{abstract}
This article summerizes our recent studies on structures and viscoelastic properties of polymer solutions and multicomponent-mulutiphase polymer systems, particularly polyelectrolyte solutions and polymer blends. Viscoelastic properties of polyelectrolyte solutions can be understood by classifying the solutions at least into dilute, semidilute and concentrated regions almost similarly to non-ionic polymer solutions, and they can be explained by a reptation model with electrostatic interactions in the semidilute region. Viscoelastic properties of polymer blends are different in miscible and immiscible regions, and regions close to phase separation temperature. In the miscible region polymer blends behave like polymer solutions when one of two components is not entangled. In the immiscible region first normal stress difference $\mathrm{N}_{1}$ as well as shear stress are proportional to shear rate in accordance with the theory of textured materials presented by Doi and Ohta. In the two-phase region close to phase separation temperature, the shear rate dependence of $\mathrm{N}_{1}$ changes with shear rate owing to shear-induced homogenization. The similar shear rate dependence of $\mathrm{N}_{1}$ is also observed for block copolymers in the ordered region close to orderdisorder transition, but it is due to the orientation of lamellar domains.

Key Words: polyelectrolyte solutions/dilute region/ semidilute region/concentrated region/ reptation model/ polymer blends/ textured materials/ shear-induced homogenization/ block copolymers/ orientation of lamellar domains/
\end{abstract}

\section{高分子溶液および多成分多相系の構造と粘弾性}

$$
\text { 野田一郎 }
$$

（原稿受理：1996年 9 月 3 日）

\section{1.はじめに}

高分子の研究を始めた時より, 高分子物性の分子レベルでの解 明に関心を持っていたので, 高分子電解質と非電解質高分子の希 薄溶液の熱力学的および流体力学的性質に関する研究を行った。 しかし，さらに高分子物性の分子論を深めるためには，このよう な希薄溶液の分子レベルでの知見を漫厚溶液などの凝集系に展開 する必要があると考えた。そこで分子量分布の狭い陚料を用い

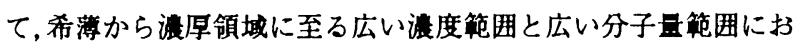
いて, 良溶媒系高分子溶液の熟力学的性質および粘弾性の研究を

名古屈大学大学院工学研究科物化学定政 $\$ 464.01$ 名古展市千租区不老町
行ない,さらに引き続き, 広い浱度範囲にわたる高分子電解質溶 液の粘弾性の研究を行ってきた. その結果, 各濩度領域における 電解質および非電解質高分子溶液の特徽を明らかにすることがで きた，また，凝集系への更なる展開として，高分子多成分多相系 であるポリマーブレンドおよびブロック共重合体のミクロ相分離 構造の棈造と粘弾性に関する研究を行ってきた，その結果, ポリ マーフレンドについては, 相溶, 非相溶領域および相分離点近傍 に分けて議論し,各領域の高分子混合系の粘弾性の特徽を明らか にした. ブロック共重合体については, 分子形状の異なる種々の 二元, 三元ブロック・クラフト共重合体のミクロ相分離構造のモ ルフォロジーの組成依存性扔よびそれらのラメラ構造の恒等周期 の分子量依存性の特對を明らかにすると共に, 中性子小角散乱に 
より,ミクロ相分醮構造を分子レベルで研究した，また，その粘 弾性については, ボリマーブレンドと同様に秩序，無秩序領域扔 よび転移点近傍の領域に分けて議論し，各領域の粘弾性の特徽を 研究している.ここでは柇面の都合もあるので，高分子電解質を 中心とした高分子溶液の粘弾性とボリマーフレンドを中心とした 高分子多成分多相系の構造と粘弾性について述べる.

\section{2. 高分子溶液の粘弾性}

- 高分子電解䁈溶液を中心に

始めに, 比較のために良溶媒系高分子溶液の粘弾性，すなわち 零ずり粘度 ク゚と定常状態コンブライアンス Jeの結果について簡 単に述べる. $\eta^{0}$ は, 熱力学的性質である浸透圧などと同様に, 高 分子浱度 $\mathrm{C}$ とポリマーコイルの重なり度合 $\mathrm{C} / \mathrm{C}^{*}$ を浱度バラメー 夕として, 少なくとも希薄, 準希薄, 浱厚の三領域に分けて議諭 される。このC゙はポリマーコイルが重なり始める䧗界浱度を示 し, 次式で与えられる11,2).

$$
\mathrm{C}^{*}=3 \mathrm{M} /\left(4 \pi<\mathrm{S}^{2}>^{3 / 2} \mathrm{~N}_{\mathrm{A}}\right)
$$

ここで $\mathrm{M},<\mathrm{S}^{2}>$ および $\mathrm{N}_{\mathrm{A}}$ はそれぞれ分子量，平均自乗回転半径 およびアボガドロ数である．粘度に関する重なりの臨界瀑度 $\mathrm{C}_{\mathrm{v}}$ * より低い濐度，すなわち粘度についての希薄領域 $\left(\mathrm{C}<\mathrm{C}_{\mathrm{v}}{ }^{*}\right)$ では， 逼元零ずり粘度 $\eta_{\mathrm{R}}^{0}\left(\approx \eta_{\mathrm{pp}}^{0} / \mathrm{C}[\eta], \eta_{\mathrm{sp}}^{0}=\left(\eta^{0}-\eta_{\mathrm{g}}\right) / \eta_{\mathrm{z}}, \eta_{\mathrm{g}}\right.$ は溶媒粘度お よび $[\eta]$ は固有粘度) は重なり度合 $\mathrm{C} / \mathrm{C}^{*}$ あるいは $\mathrm{C}[\eta]$ の展開型 で与えられる。な报， $\mathrm{C}^{*}$ 、は $\mathrm{C}^{*} に$ に比例するが，同一分子量で比へ れば C*より10倍程度大きい．Cが $\mathrm{C}^{*}$ 、より大きいが，ある一 定湿度 $\mathrm{C}^{* *}$ (約 $\left.0.2 \mathrm{~kg} / \mathrm{dm}^{3}\right)$ 上り小さい準希薄領域 $\left(\mathrm{C}>\mathrm{C}_{\mathrm{v}}^{*}, \mathrm{C}<\mathrm{C}^{* *}\right)$ では, 絡んでいる高分子の粘度の分子量依存性が $\eta^{0} \propto \mathrm{M}^{3.4}$ で与 えられるので, $\eta_{\mathrm{R}}^{0}$ は次のスケーリング則によって表わせる 2)-5).

$$
\eta_{\mathrm{R}}^{0} \propto\left(\mathrm{C} / \mathrm{C}^{*}\right)^{(4.4-3 \mathrm{v}) /(3 \mathrm{v}-1)} \propto(\mathrm{C}[\eta])^{(4.4-3 \mathrm{v}) /(3 \mathrm{v}-1)}(2)
$$

ここで、はくS から準希薄領域にわたって $\mathrm{C} / \mathrm{C}^{*}$ あるいは $\mathrm{C}[\eta]$ の関数となる。さ らにCが $\mathrm{C}^{* *}$ より大きい浱厚・絡み領域 $\left(\mathrm{C}>\mathrm{Cv}^{*}, \mathrm{C}>\mathrm{C}^{* *}\right)$ では, 局所摩擦係数の灌度依存性が大きくなり， $\eta_{\text {ap }}^{0}$ は準希溥領域上り 強い瀑度依存性を持ち, 従って, $\eta_{\mathrm{R}}^{0}$ はスケーリンク則から外れ る.

一方，非電解質高分子溶液の定常状態コンブライアンス J。は 希薄（非絡み）および絡みの二領域に分けて議論される。これは 絡み領域のJ。を粘度の場合のように，その裖度依存性で準希薄と

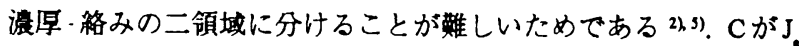
に関する重なりの郚界浱度 $\mathrm{C}_{\mathrm{J}}^{*}$ より低い希薄領城 $\left(\mathrm{C}<\mathrm{C}_{\mathrm{J}}^{*}\right)$ では, 高分子鎖はJ。については孤立し，従って，Jは次式で与えられる。

$$
\mathrm{J}_{0} \propto \mathrm{MC}^{-1}
$$

一方, 䅂み領域 $\left(\mathrm{C}>\mathrm{C}_{\mathrm{J}}\right.$ ) $)$ では, 良溶媒中の J。の濐度依存性は次 式で与えられるッ。

$$
\mathrm{J}_{0} \propto \mathrm{C}^{-2.1}
$$

この濃度依存性はスケーリング則 $\left(\mathrm{C}^{-2.25}\right)$ と勾一網目モデ $\left(\mathrm{C}^{-2}\right)$ の 間にあり，より後者に近い.なお，同じ分子量で比較すれば， $\mathrm{C}_{J}^{*}$ は $\mathrm{C}_{\mathrm{v}}^{*}$ より 5 倍程度大きいふ。

重なり度合が重要な有限浱度における高分子電解質溶液の粘弾 性については,これまでいくつかの研究がなされたが，あまり明 確な結論が得られていなかった.この主な原因の一つは分子量が 大きく，しかも分子量分布の狭い試料を用いていなかったことに よる.そこで我々はアニオン重合で得た poly(2-vinylpyridine)およ び polystyreneをそれぞれ四級化およびスルホン化した種々の分子 量の poly(N-methyl-2-vinylpyridinum chloride)(PMVPCl) $\left.{ }^{6}\right)$ と poly(sodium styrenesulfonate)(NaPSS)を試料として用い，無塩系㧍 よび添加塩系において広範に高分子浱度をかえて,各浱度領域に おける $\eta_{\text {\% }}^{0} \mathrm{~J}$ Jおよびゴム状平坦領域の弾性率 $\mathrm{G}_{\mathrm{N}}$ を検討したク-11).

準希薄領域 $\left(\mathrm{C}>\mathrm{C}_{\mathrm{v}}{ }^{*}, \mathrm{C}<\mathrm{C}^{* *}\left(\right.\right.$ 約 $\left.\left.0.3 \mathrm{~kg} / \mathrm{dm}^{3}\right)\right)$ における高分子 電解質溶液の $\eta_{\text {。 }}^{0}$ の高分子浱度依存性は, 図 1 に示すように次式 で与えられる。

$$
\eta_{\text {sp }}^{0} \propto M^{3} C^{x}
$$

ここでその高分子瀑度依存性の指数 $\mathrm{x}$ は添加塩浱度 $\left(\mathrm{C}_{\mathrm{s}}=0,0.01\right.$, $0.1,0.5 \mathrm{M})$ と共に増加 $(\mathrm{x}=1.5,1.8,2.8,4.6)$ し, 高添加塩溓度 $(0.5 \mathrm{M})$ では上述の良溶媒系高分子溶液の湦度依存性とほほ同じになるク 8). $\eta^{0} \propto \mathrm{M}^{3}$ を用いると, 準希薄領域において $\eta_{\mathrm{R}}^{0} \propto(\mathrm{C}[\eta])^{(4-3 v)(3 \cdots 1)}$ るスケーリング則が得られる. 高分子浱度依存性から予測される ように高添加塩浱度 $(0.5 \mathrm{M})$ ではスケーリング則に従うが，低添 加塩瀑度 $(0.01 \mathrm{M})$ では従わない7), 8).

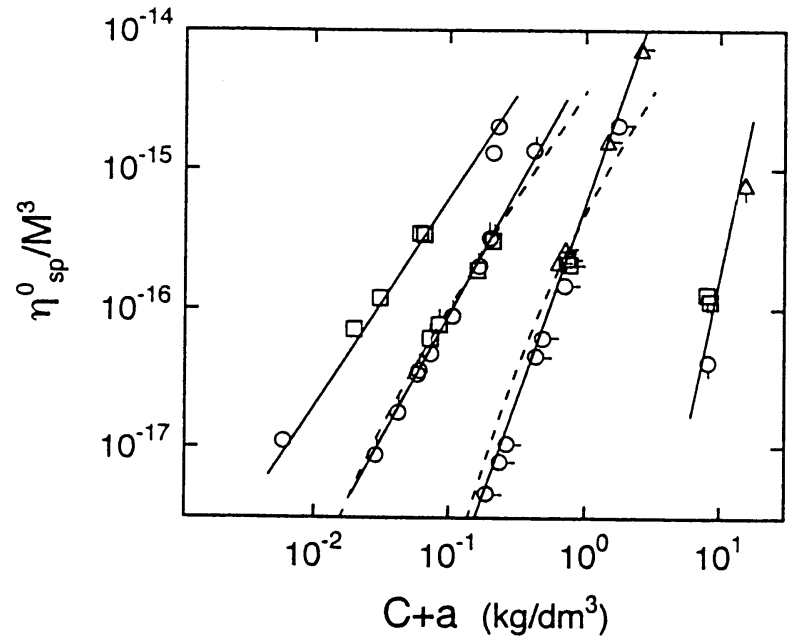

Fig. 1. Double logarithmic plots of $\eta^{0}{ }^{2} \mathrm{M}^{3}$ vs. $\mathrm{C}$ for $\mathrm{PMVPCl}$ in the absence and presence of added salt. Triangles, squares and circles denote the data for $\mathrm{PMVPCl}$ with $\mathrm{M}_{w}=694 \mathrm{~K}, 1100 \mathrm{~K}$ and $2740 \mathrm{~K}$, respectively Upward, rightward and downward pips indicate the data in 0.01, 0.1 and $0.5 \mathrm{M} \mathrm{NaCl}$ solutions., respectively. Symbols without pip denote the data in salt-free solutions. The solid and broken lines denote eqs 5 and 9 , respectively. Both lines coincide with each other in salt-free and $0.5 \mathrm{M}$ $\mathrm{NaCl}$ solutions. 
$\mathrm{C}$ がC**より大きくなると, 图 2 に示すように, $\eta_{\text {中⿰氵 }}^{0}$ は C と共 に急激に増加する.これは良溶媒系高分子溶液と同様に局所摩㨲 係数の湌度依存性が大きくなるためであると考えられる。そこで この領域を浱厚一絡み領域 $\left(\mathrm{C}>\mathrm{C}_{\mathrm{J}}^{*}, \mathrm{C}>\mathrm{C}^{* *}\right)$ と呼ぶ.

図 3 に示すように, 希薄領域 $\left(\mathrm{C}<\mathrm{C}_{\mathrm{J}}^{*}\right)$ におけるJ.の実験デー 夕は，分子量，添加塩瀑度に依存し，次式で表わされる7，81.

$$
\mathrm{J}_{\mathrm{e}} \propto \mathrm{C}^{-3} \mathrm{M}^{-2} \mathrm{C}_{\mathrm{s}}
$$

この結果は良溶媒系高分子溶液（3式）と著しく異なり, 強い 静電相互作用によるものと考えられる.

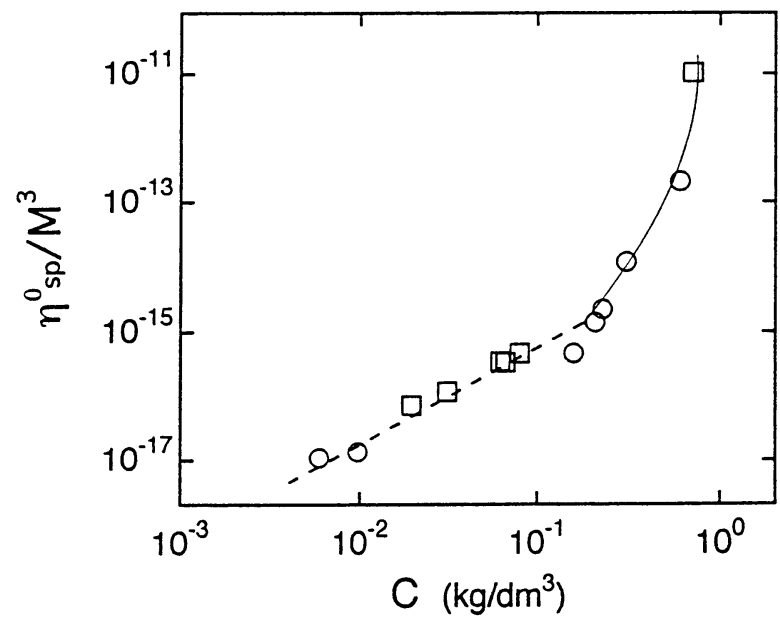

Fig. 2. Polymer concentration dependence of $\eta_{\mathrm{p}}^{0}$ for $\mathrm{PMVPCl}$ in salt-free solutions in the semidilute region and the concentrated and entangled region. Symbols are the same as in Fig. 1. The broken line denotes eq 5 with $\mathrm{x}=1.5$ and the solid line is drawn as a guide to show the steep increase of viscosity in the concentrated and entangled region.

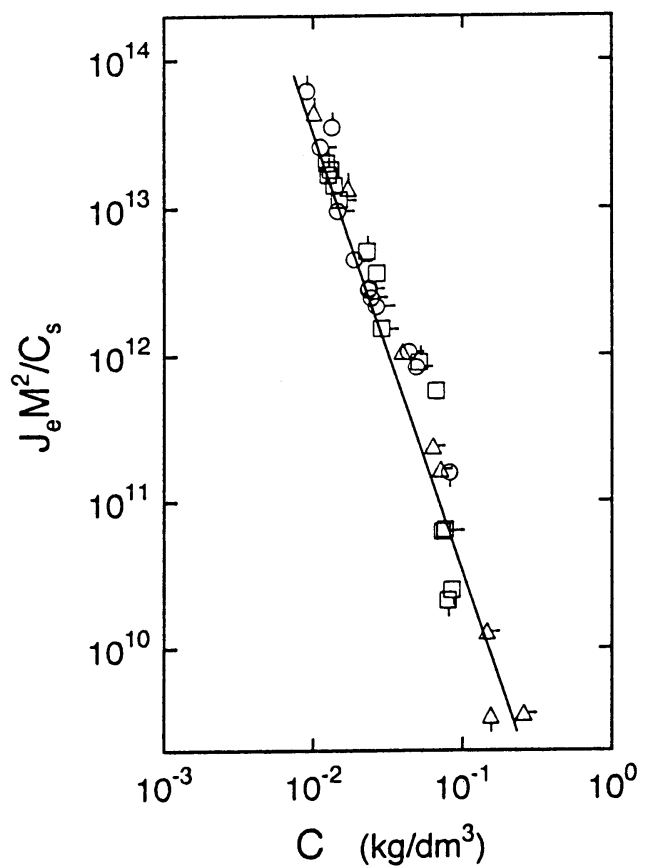

Fig . 3. Double logarithmic plots of $\mathrm{J}^{\mathrm{M}} \mathrm{M}^{2} \mathrm{C}, \mathrm{vs}$. $\mathrm{C}$ for $\mathrm{PMVPCl}$ in the dilute region. Symboles are the same as in Fig. 1. The line denotes eq 6 .
準希薄領域 $\left(\mathrm{C}>\mathrm{C}_{\mathrm{J}}^{*}, \mathrm{C}<\mathrm{C}^{* *}\right)$ では, 図 4 に示すように, J。は非 電解質高分子と同様に分子量, 添加塭浱度に無関係になり, 次式 で与えられるか８.

$$
\mathrm{J}_{\mathrm{e}} \propto \mathrm{C}^{-1.3}
$$

ただし，この濃度依存性は良溶媒系高分子溶液（4式）より低い． CがC*゙よ大きくなると，図5に示すように，Jは７式より 外れ，

$$
\mathrm{J}_{\mathrm{e}} \propto \mathrm{C}^{-2}
$$

で与えられる. 従って, この領域を浱厚 - 絡み領域 $\left(\mathrm{C}>\mathrm{C}_{\mathrm{J}}^{*}, \mathrm{C}>\right.$ $\left.\mathrm{C}^{* *}\right)$ と呼ふ9．この依存性は良溶媒系高分子溶液の場合 (4式)に ほほ等しく，均一網目モデルで説明される。

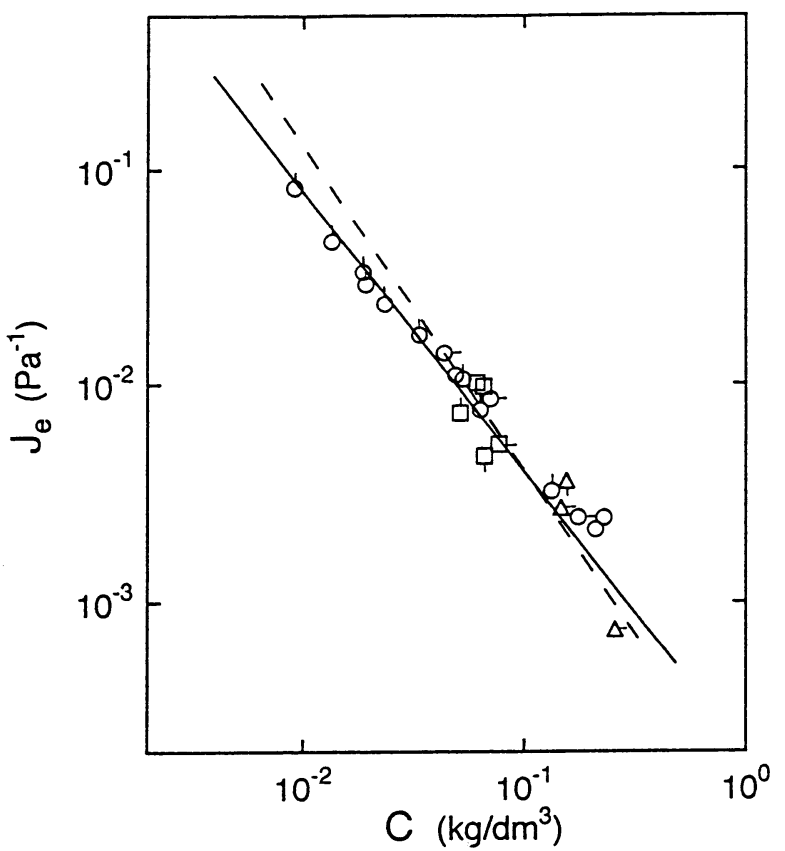

Fig. 4. Polymer concentration dependence of $\mathrm{J}$, for $\mathrm{PMVPCl}$ in the semidilute region. Symbols are the same as in Fig. 1. The solid and broken lines denote eqs 7 and $10 \mathrm{~b}$, respectively.

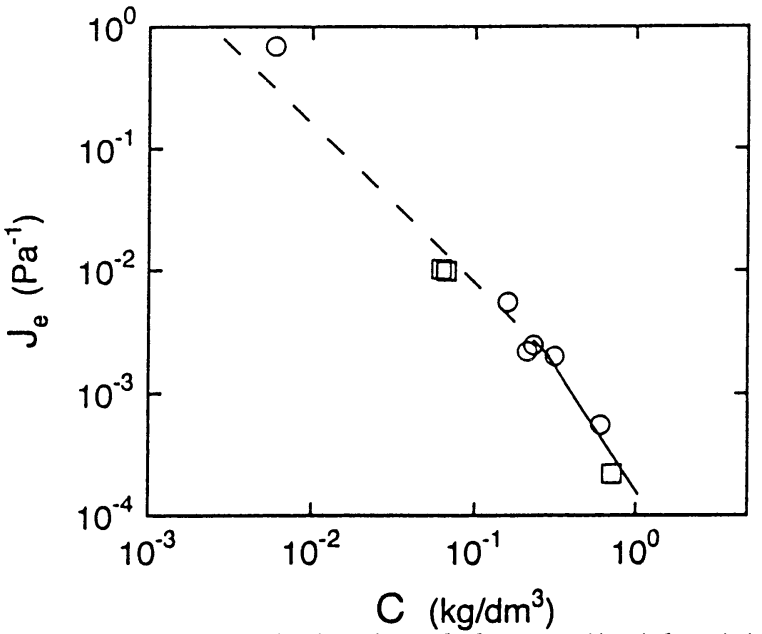

Fig. 5. Polymer concentration dependence of $\mathrm{J}$. for $\mathrm{PMVPCl}$ in salt-free solutions in the concentrated and entangled region. Symbols are the same as in Fig. 1. The slopes of solid and broken lines are -2 and -1.3 , respectively. 
なお,ゴム状平坦領域の弾性率 $\mathrm{G}_{\mathrm{N}}$ あるいは $\mathrm{G}^{\prime}$ と $\mathrm{G}^{\prime}$ の交点の 弾性率 $\mathrm{G}_{\mathrm{x}}$ は非電解質高分子と同様に港度領城によらず J。に比 例する9?.

重量平均緩和時間 $\tau_{w}\left(=\eta^{0} J_{0}\right)$ は，图 6 に示すように，希薄領域 $\left(\mathrm{C}<\mathrm{C}_{\mathrm{J}}^{*}\right)$ においてはC と共に減少する。一方, 準希薄領域 $(\mathrm{C}>$ $\left.\mathrm{C}_{\mathrm{J}}^{*}, \mathrm{C}<\mathrm{C}^{* *}\right)$ においては, $\tau_{w}$ は5 5 と 7 式の積で与えられ, 図 7 に 示すように, $\mathrm{C}$ と共に増加する. 後者は非電解質高分子の場合と 同様であるが，前者は異なるか,812)．浱厚一絡み領域 $\left(\mathrm{C}>\mathrm{C} J \mathrm{~J}^{*}, \mathrm{C}\right.$ $>C^{* *}$ )においては，図8に示すように，この領域の $\eta^{0}$ の急激な

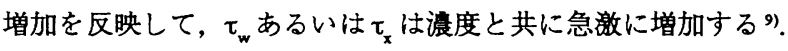

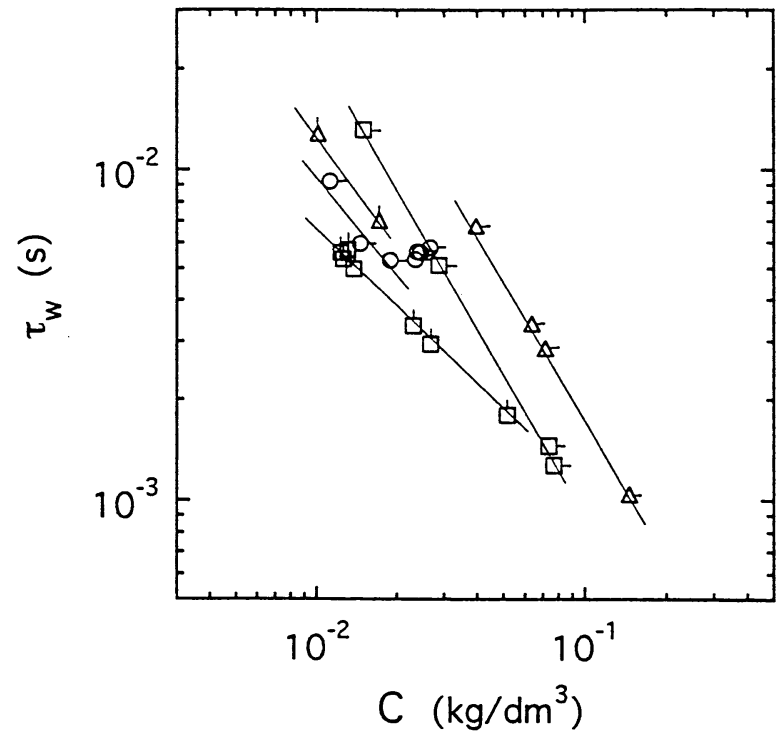

Fig. 6. Polymer concentration dependence of $\tau_{w}$ in the dilute region for $J_{e}$ Symbols are the same as Fig. 1. Upward and rightward pips denote the data in 0.01 and $0.1 \mathrm{M} \mathrm{NaCl}$ solutions, respectively.

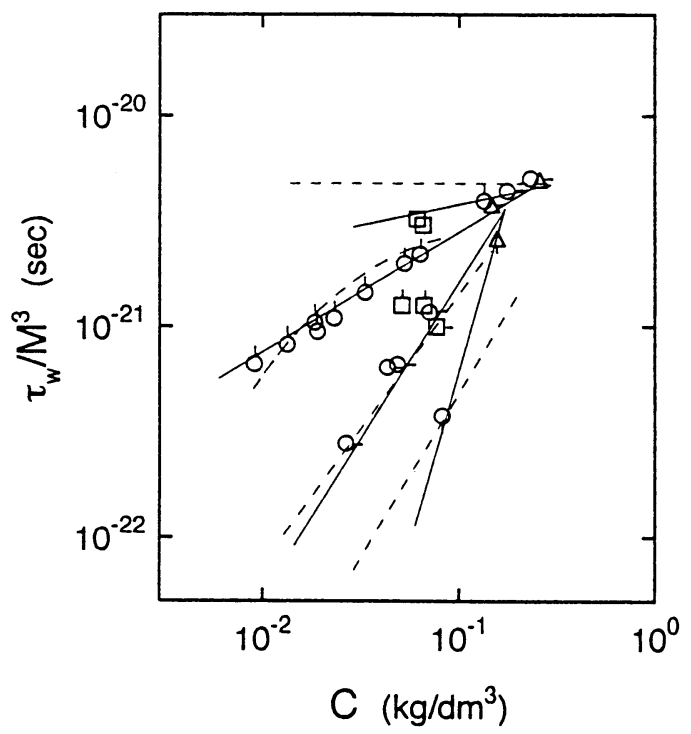

Fig. 7. Double logarithmic plots of $\tau_{n} / M^{3}$ vs. $C$ in the absence and presence of added-salt in the semidilute regions for $\eta^{\circ}$ and $\mathrm{J}$. Symbols are the same as in Figure 1. The solid and broken lines denote empirical equations obtained from the products of eqs 5 and 7 , and eq 11 , respectively, in salt-free, $0.01,0.1$ and $0.5 \mathrm{M} \mathrm{NaCl}$ solutions from top and bottom.

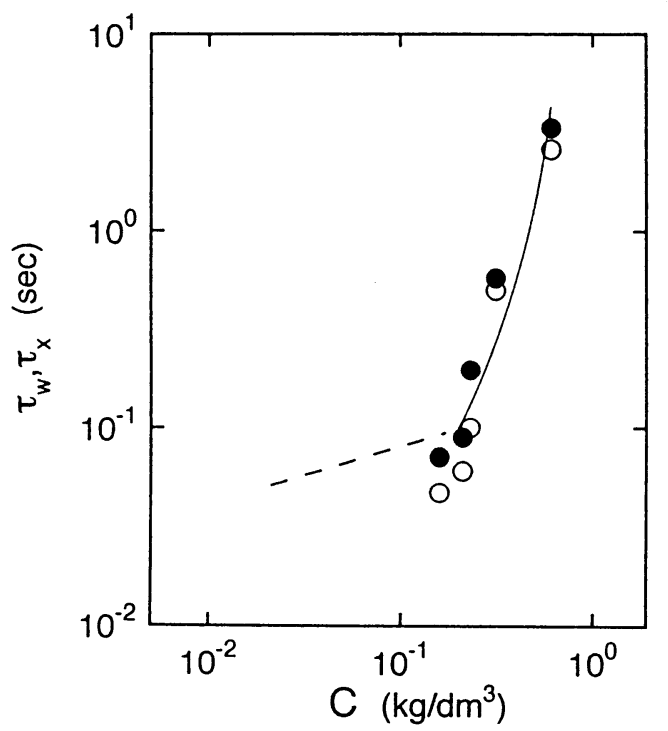

Fig. 8. Polymer concentration dependence of $\tau_{\bar{w}}(\mathrm{O})$ and $\tau_{\mathrm{x}}(\bullet)$ for PMVPCl with $M_{w}=2740 \mathrm{~K}$ in salt-free solutions in the concentrated and entangled region. The broken line denotes the data in the semidilute region. The solid line is drawn as a guide to show the steep increase of the relaxation times in the concentrated and entangled region.

ここで $\tau_{x}$ は $\mathrm{G}_{x}$ における角周波数の逆数である.

なお，高い高分子濃度 (例えば $\mathrm{C}=0.49 \mathrm{~kg} / \mathrm{dm}^{3}$ )における低分子 量高分子電解質 (例えば $\mathrm{M}=179 \mathrm{~K}$ ) の粘弾性の角周波数依存性に は，ゴム状平坦領域が現れない。従って，この領域を浱厚一非絡 み領域と呼ふ。その依存性は非電解質高分子の場合と同様に， Rouse モデルで説明される ${ }^{10)}$.

我々は,ドナン平衡により静電相互作用を考虑して,レプテー ションモデルに基づく準希薄領域の高分子電解質溶液の粘弾性理

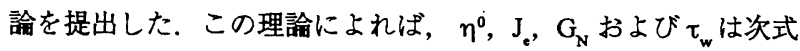
で与えられるク,8.

$$
\begin{aligned}
& \eta_{\mathrm{sp}}^{0} \propto \mathrm{N}^{3}\left[\left(\mathrm{i}^{2} \mathrm{c}^{2}+4 \mathrm{C}_{\mathrm{s}}^{2}\right)^{1 / 2}-2 \mathrm{C}_{\mathrm{s}}\right]^{9 / 4} \mathrm{c}^{-3 / 4} \\
& \mathrm{~J}_{\mathrm{e}} \propto 1 / \mathrm{G}_{\mathrm{N}} \propto\left[\left(\mathrm{i}^{2} \mathrm{c}^{2}+4 \mathrm{C}_{\mathrm{s}}\right)^{1 / 2}-2 \mathrm{C}_{\mathrm{s}}\right]^{-3 / 4} \mathrm{c}^{-3 / 4} \\
& \tau_{\mathrm{w}} \propto \tau \propto \mathrm{N}^{3}\left[\left(\mathrm{i}^{2} \mathrm{c}^{2}+4 \mathrm{C}_{\mathrm{s}}{ }^{2}\right)^{1 / 2}-2 \mathrm{C}_{\mathrm{s}}\right]^{3 / 2} \mathrm{c}^{-3 / 4}
\end{aligned}
$$

ここでNは高分子のセグメント数，iはセグメント当りの有効電 荷量, c は単位体積当りのセクメント数である $(\mathrm{c} \propto \mathrm{C})$ ）もし添加 坦漉度が高いならば (C, 》ic), これらの式は良溶媒系高分子溶 液のスケーリンク則に対応する関係になる， $\eta_{\text {甲 }}^{0}$ の実験值は図 1 に示すように9式でよく説明されるわ，ま．また，Jの準希薄領城で はC 、《 icなる条件がはは成り立ち，その条件下では10a式は次 のようになる。

$$
\mathrm{J}_{0} \propto 1 / \mathrm{G}_{\mathrm{N}} \propto \mathrm{C}^{-3 / 2}
$$

J.の渡度依存性の実験值は図4に示すように10b式ではほ説明さ れる》。．さらに，各添加坦㳻度における $\tau_{\mathrm{w}}$ の高分子港度依存性 も図7に示すように 11 式で説明されるク，8. 
3．高分子多成分多相系の構造と粘弾性 ーポリマーブレンドを中心に

高分子多成分多相系,すなわちポリマーブレンドやブロック共 重合体などの粘弾性は構造に依存するため, その溶解, 分散状態 により大きく異なる.また, 流動により相溶性が影隌を受けるこ とも知られている.そこでポリマーブレンドの粘弾性を相溶, 非 相溶抢よび相分離近傍の三領域に分けて検討した。

相溶領域のポリマーフレンドの粘弾性は絡み状態,従って構成 高分子成分の分子量と組成に依存すると考えられる，そこでま ず，我々は相溶性ポリマーブレンドの成分高分子として polystyrene(PS) と polyvinylmethylether(PVME)を㟟び，最も単純な 系の一つ, 即ち $\mathrm{AB}$ 二成分ブレンドの $\mathrm{A}$ 成分(PVME) は分子量が 小さいため絡みに寄与せず, B成分(PS)のみが寄与する系におい て，ポリマーブレンドの粘弾性に及ばす $\mathrm{B}$ 成分(PS)の分子量 $\mathrm{M}_{\mathrm{Ps}}$

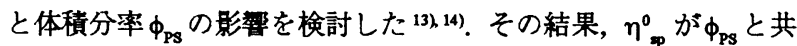
に急激に增加する筷界の体積分率 $\phi_{\mathrm{ps}}^{*}$ は $\mathrm{M}_{\mathrm{ps}}$ と間に $\phi_{\mathrm{ps}}^{*} \propto \mathrm{M}_{\mathrm{ps}}{ }^{-0.6}$ なる関保があり，高分子溶液と同じように， $\phi_{\mathrm{PS}}>\phi_{\mathrm{ps}}^{*}$ では，図 9 に示すように, $\eta^{0}$, $\propto \mathrm{M}^{3}$ として得たスケーリング則 (12 式, $v=0.53)$ に従うこと，また，図10に示すように, $\mathrm{G}_{\mathrm{N}}$ も溶液とほほ 同様に 13 式に従うことを明らかにした。

$$
\begin{aligned}
& \eta_{\mathrm{sp}}^{0} \propto\left(\phi_{\mathrm{PS}} / \phi_{\mathrm{PS}}^{*}\right)^{3 /(3 \mathrm{v}-1)} \\
& \mathrm{G}_{\mathrm{N}} \propto \phi_{\mathrm{PS}}{ }^{2}
\end{aligned}
$$

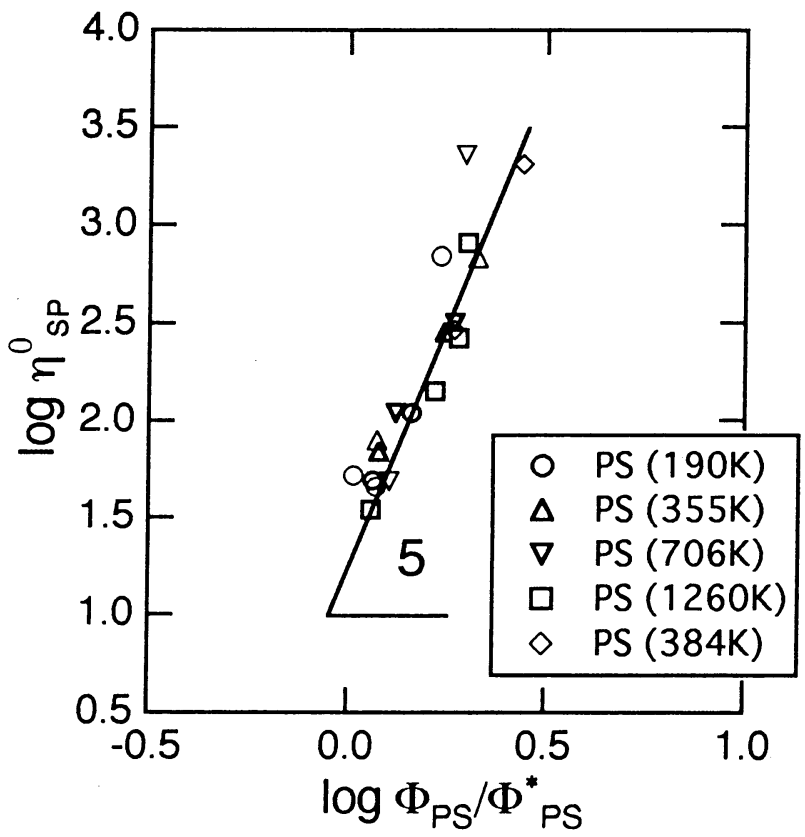

Fig. 9. Double logarithmic plots of $\eta^{0}$ against $\phi_{P 8} / \phi_{P B}^{*}$ for miscible PS/PVME blends. Different symbols denote the polystyrenes with different molecular weights as shown in the figure. The solid line denotes $\eta^{0} \propto$ $\phi_{\mathrm{Pg}}{ }^{5}$, which is predicted by eq 12 with $v=0.53$.
非相溶高分子混合系は流動により各相のドメインが複雑な構造 変化を起こすので, その粘弾性挙動は複雑になると考えられる. この系の粘弾性についてはボリマーブレンドの成型加工や力学的 性質との関保で多くの研究があるが,学問的な研究は殆どなされ ていなかった．最近，土井·太田はこの系のモデルとなりえる Textured Materials の構成方程式を組成 1：1の2成分非相溶 ニュートン液体に対して導き,興味あるスケーリンク関係がある ことを示した ${ }^{13)}$. 彼らの理論によれば，定常ずり流動場におい て, 次式のようにずり応力 $\sigma_{12}$ ばかりでなく, 第一法線応力差 $\mathrm{N}_{1}$ もずり速度市に比例すること，

$$
\begin{aligned}
& \sigma_{12} \propto \dot{\gamma} \\
& \mathrm{N}_{1}\left(=\sigma_{11}-\sigma_{22}\right) \propto \dot{\gamma}
\end{aligned}
$$

また, 初期のずり速度 $\dot{\gamma} \mathrm{t}=0$ で瞬時に最終のずり速度 $\dot{\gamma}_{\mathrm{f}} に$ 変 化させた場合, 最初の応力で規格化した時間後の非定常応力は, $\dot{\gamma}_{\mathrm{f}} / \dot{\gamma}_{\mathrm{i}}$ が一定ならば, 次式のように歪 $\mathrm{t} \dot{\gamma}_{\mathrm{f}}$ の普遍関数となることが 予測される。

$$
\begin{aligned}
& \sigma_{12}\left(t, \dot{\gamma}_{i}, \dot{\gamma}_{f}\right) / \sigma_{12}\left(\dot{\gamma}_{i}\right)=f_{\sigma}\left(t \dot{\gamma}_{f}, \dot{\gamma}_{f} / \dot{\gamma}_{i}\right) \\
& \mathrm{N}_{1}\left(t, \dot{\gamma}_{i}, \dot{\gamma}_{f}\right) / N_{1}\left(\dot{\gamma}_{i}\right)=f_{N}\left(t \dot{\gamma}_{f}, \dot{\gamma}_{f} / \dot{\gamma}_{i}\right)
\end{aligned}
$$

我々は彼らの理論が対象にしている組成 $1: 1 の 2$ 成分非相溶 ニュートン液体ばかりでなく,組成の異なる系や粘弾性を示す高 分子を構成成分とする 2 成分非相溶高分子混合系について定常す り流動およびずり速度のステッブ変化後の粘弾性を実験的に検討

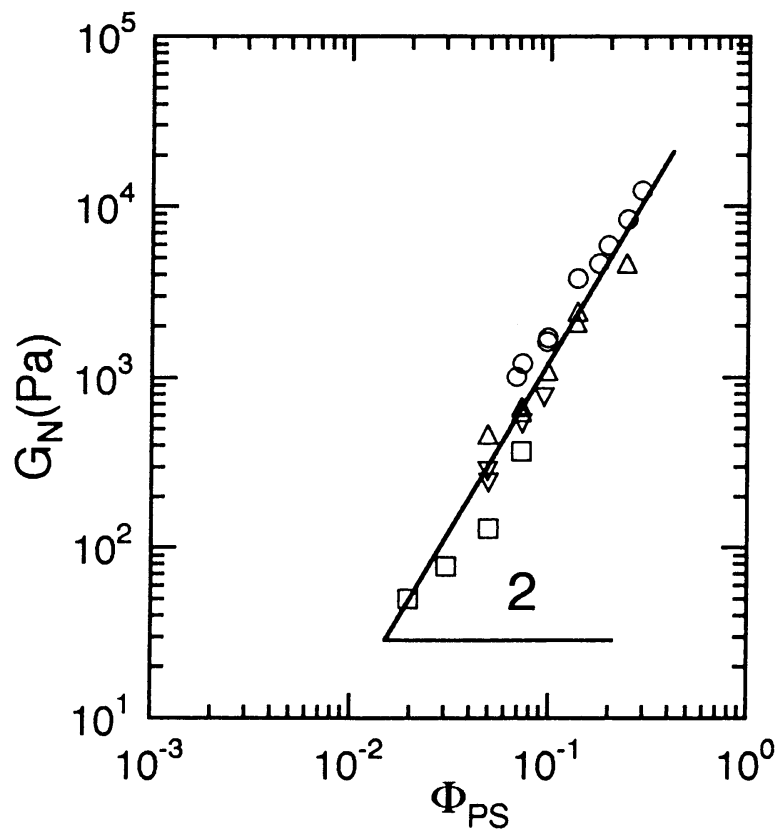

Fig. 10. Double logarithmic plots of $G_{N}$ against $\phi_{P g}$ for miscible PS/PVME blends Symbols are the same as in Fig. 9. 


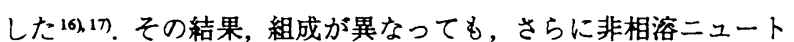
ン液体のみならず，それぞれ単独で粘弾性挙動を示す polydimethylsiloxane(PDMS) と polybuthadiene(PB) との非相溶高分 子混合系についても，理論が予湘するように， $\sigma_{12}$ (図 11）ばか りでなく，図12に示すように, $\mathrm{N}_{1}$ も文に比例することを明らかに

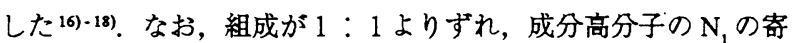
与が大きくなる場合は, 成分高分子の寄与を差し引くならば, 一 乗の依存性を示す。この $\mathrm{N}_{1}$ の一乗のずり速度依存性は，二乗の

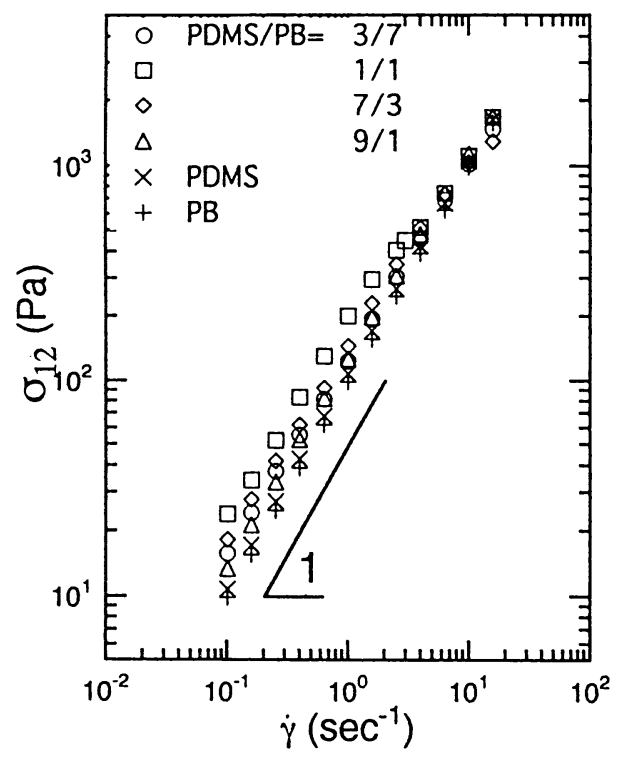

Fig. 11. Double logarithmic plots of shear stress $\sigma_{12}$ for PDMS/PB blends against shear rate $\dot{\gamma}$. The data for the component polymers are also shown for comparison. Symbols are denoted in the figure.

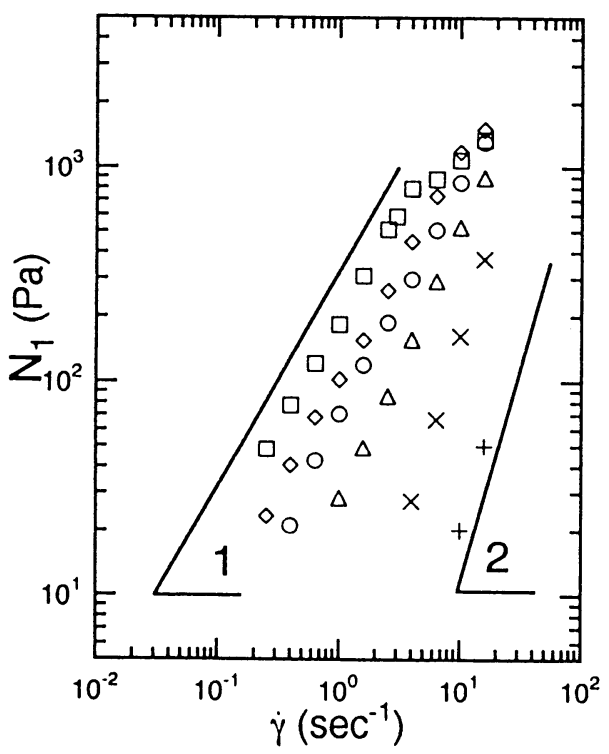

Fig. 12. Double logarithmic plots of first normal stress difference $N_{1}$ for PDMS/ PB blends against shear rate $\dot{\gamma}$. The data for the component polymers are also shown for comparison. Symbols are the same as in Fig. 11
依存性を示す均一高分子系とは異なり, 界面張力の寄与を示す非 相溶混合系の著しい特徽である。

また, 非相溶ニュートン液体ばかりでなく, 非相溶高分子混合 系についても，ステッブ変化後の応力変化 (図 13) をステップ変 化前の応力で規格化すると, 図 14, 15 に示すように, 理論の予 測に従い, 歪 $\mathrm{t} \dot{\gamma}_{\mathrm{f}}$ の関数となるが, $\sigma_{12}$ ではアンダーシュート, $\mathrm{N}_{1}$ ではオーバシュートを示し,その远移挙動は理論の予測とは異な

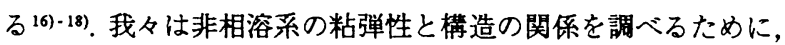
ビデオ顥徽鏡により流動下のドメイン構造を観測した。その結 果，定常ずり流動ではドメインの大きさは，図16に示すように 理論の予測に従い，ほほ $\dot{\gamma} に 反$ 比例して小さくなること，また非 定常ずり流動において現れるアンダーシュートやオーバシュート は㟟移過程におけるドメイン構造の伸張, 崩壊過程と密接に関係 していることを明らかにした ${ }^{18), 199 .}$

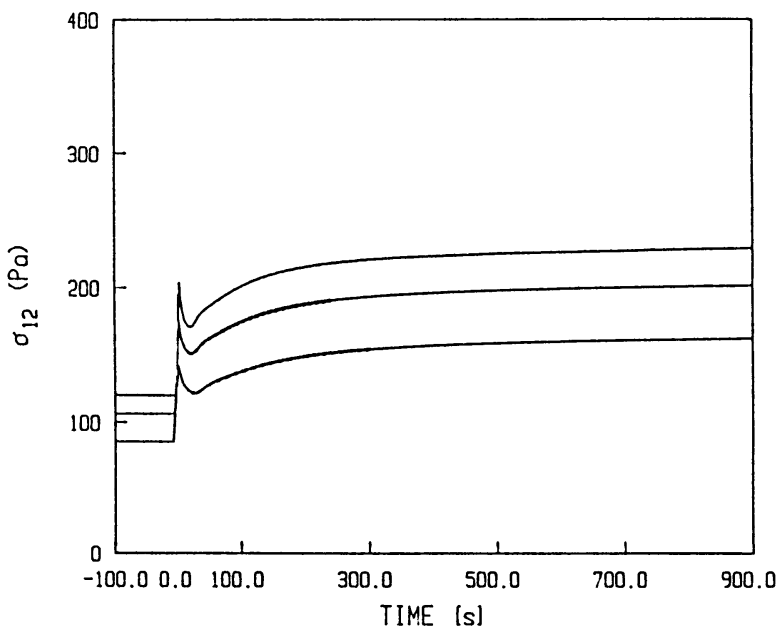

Fig. 13. Transient shear stresses after step increase of shear rate for PDMS/PB blend with the composition of $1: 1$. The lines denote the data for step increases of shear rate $\left(\mathrm{s}^{-1}\right)$ from 0.6 to 1.2 , from 0.5 to 1.0 and from 0.4 to 0.8 from top to bottom.

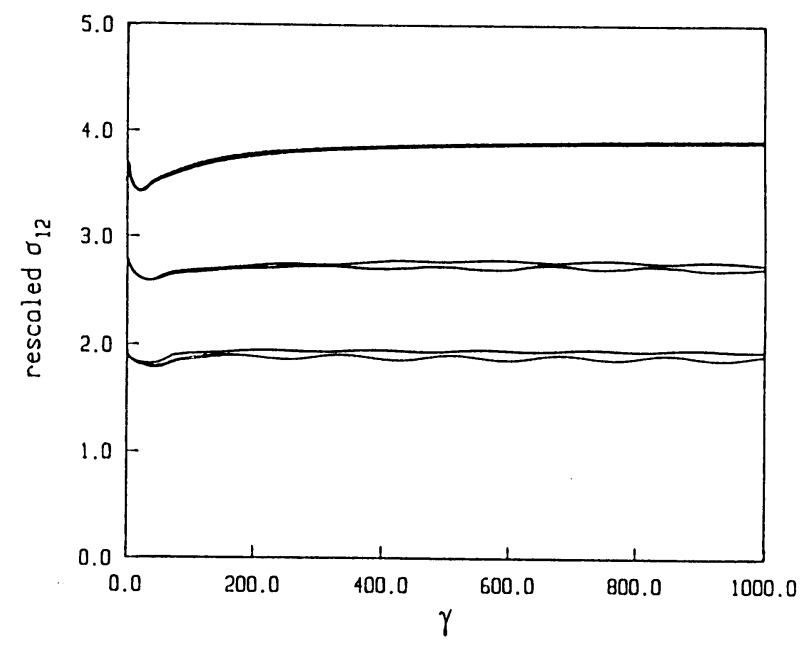

Fig. 14. Plots of rescaled shear stress against strain at fixed shear rate ratio $\left(\dot{\gamma}_{d} / \dot{\gamma}_{i}\right.$ 2). Compositions of blends are 1:1, 7:3 and 9:1 for PDMS:PB from top to bottom. The data for $1: 1$ blend and 7:3 blend are vertically shifted by +2 and +1 , respectively. 


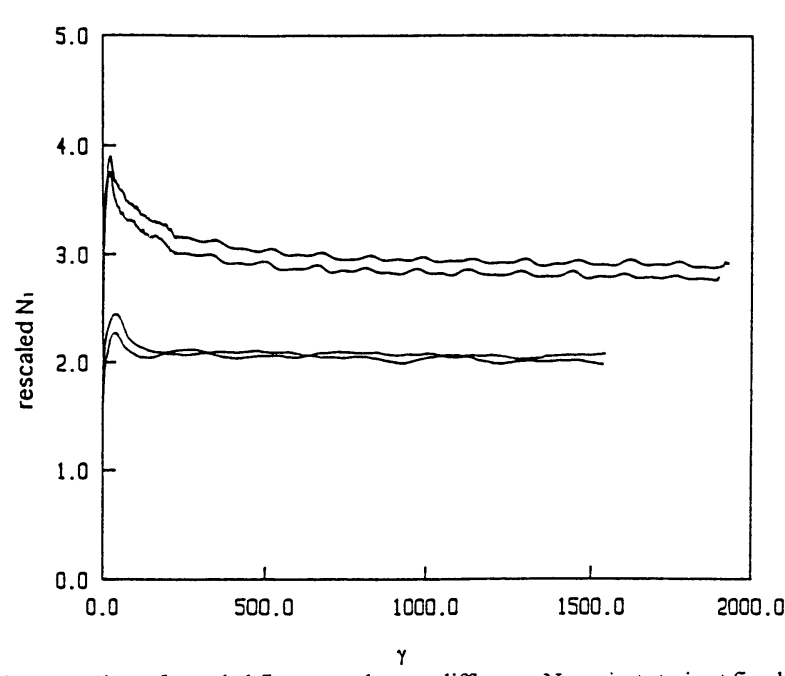

Fig. 15. Plots of rescaled first normal stress difference $\mathrm{N}_{1}$ against strain at fixed shear rate ratio $\left(\dot{\gamma}_{f} \dot{\gamma}_{i}=2\right)$. Compositions of blends are $1: 1$ and 7:3 for PDMS:PB from top to bottom. The data for $1: 1$ blend are vertically shifted by +1 .

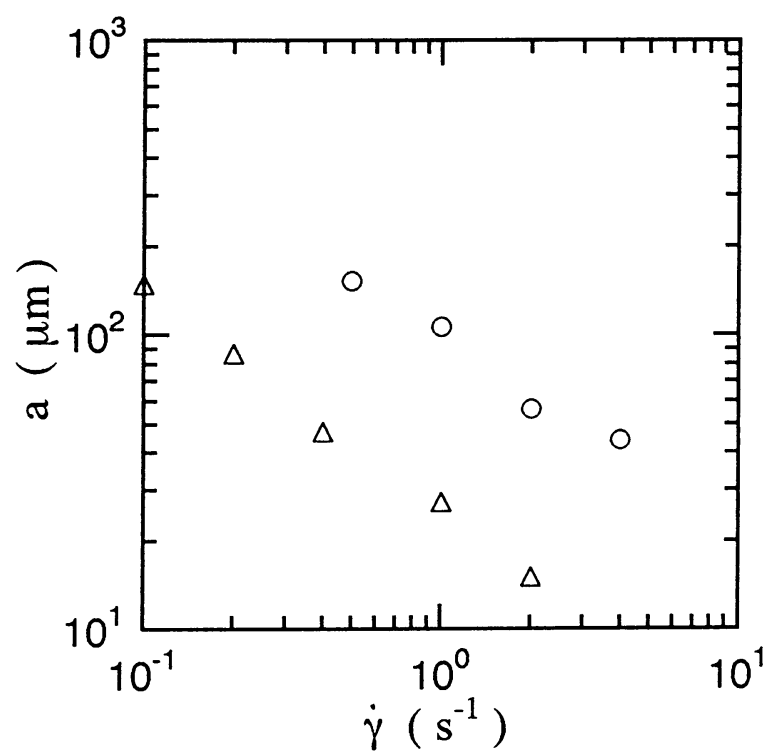

Fig. 16. Double logarithmic plots of drop size (a) against shear rate $\dot{\gamma}$ for silicone oil/ resin oil $(O)$ and PDMS/polyisoprene $(\Delta)$ blends.

相分離点近傍の二相領域のポリマーブレンドにずり流動を与え ると相溶化が起こることが知られている。そこで我々はほほは繁界 組成を持つPS/PVMEブレンドについて，相分離点近傍における 定常ずり流動下での粘弾性を検討した。一相領域では，予測され るように均一高分子系と同様な挙動を示す，一方，図17に示す ように, 二相領城では, $\dot{\gamma} の$ 低い場合は, 上記の非相溶混合系と同 様に $\sigma_{12}$ と $\mathrm{N}_{1}$ 共にずり速度の一乗の依存性を示すが, 刘高くなる と, $\mathrm{N}_{1}$ は二乗の依存性を示すようになり, 粘弾性的にも相溶化が 観測される20),21).

秩序-無秩序転移点近傍における秩序状熊，すなわちラメラ構 造を持つ 2 元ブロック共重合体に定常ずり流動を与えた場合，゙ リマーブレンドと同様に $\mathrm{N}_{1}$ のずり速度依存性が一采から二乗に

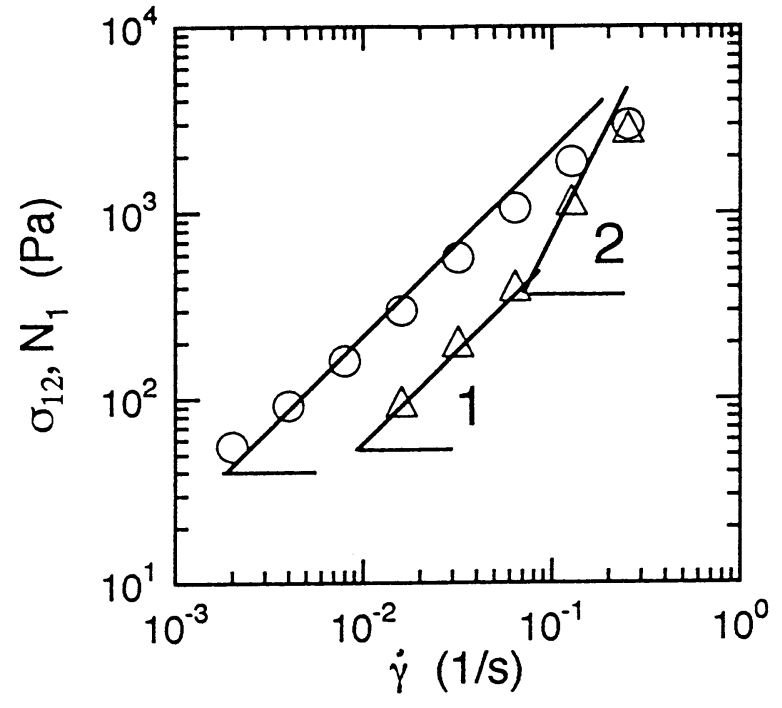

Fig. 17. Shear rate dependences of shear stress $\sigma_{12}(O)$ and first normal stress difference $\mathrm{N}_{1}(\Delta)$ for PS/PVME blends in the two-phase region near phase separation temperature at quiescence.

変化することが観察された.この原因がポリマーブレンドで見ら れた相溶化なのか, 振動ずりをミクロ相分離構造に与えた時に見 られた眍向化なのかについては粘弾性のみからは判断できない. そこで流動下の中性子小角散乱および複屈折測定を行った結果, ラメラ構造の配向によることを明らかにした 22).

\section{4.おわりに}

高分子溶液の粘弾性は, 非電解質高分子, 高分子電解質共に, 基本的には希薄, 準希薄, 㬊厚の 3 領域に分けて議論できるこ と,準希薄領域に抢いては非電解質高分子ではスケーリング則が 成り立つが, 高分子電解質では高添加塩浱度でのみ成り立ち, 一 般には静電相互作用を考虑したレブテーションモデルにより理解 できることを示した，なお，希薄領域における高分子電解質の は, 非電解質高分子のそれとは著しく異なり, 強い静電相互作用 を受けていると考えられるが,理論的にはまだ明らかにされてい ない.

ポリマーブレンドの非相溶系の粘弾性の特徽は土井·太田らの 理論により理解されることがかなり明らかになったが,相溶系や 相分醮近傍の粘弾性についてはさらに系統的な研究が望まれる。 ブロック共重合体の粘弾性については系統的な研究が始まったと ころであり，今後の展開に期待したい.

\section{謝辞}

この度, 日本レオロジー学会賞をいただいだ連の研究は私だ けの成果ではなく,研究室の内外の多くの方々との共同研究の成 果であることは言うまでもありません，舴面の都合上，皆様のお 名前を記すことはできませんが,ここで改めて心から扔礼申し上 げます。 


\section{参考文献}

1) de Gennes P. G., "Scaling Concepts in Polymer Physics", Cornell Univ. Press, Ithaca, NY., 1979.

2) Noda I, In "Molecular Conformation and Dynamics of Macromolecules in Condensed Systems", M. Nagasawa, Ed., Elsevier, Tokyo, p. 85, 1988.

3) de Gennes P. G, Macromolecules, 9, 587 (1976).

4) Takahashi $Y$, Isono $Y$, Noda I and Nagasawa $M$, Macromolecules, 18, 1002 (1985).

5) Takahashi $Y$, Noda I and Nagasawa M, Macromolecules, 18, 2220 (1985).

6) Yamaguchi M, Yamaguchi Y, Matsushita $Y$ and Noda I, Polym. J., 22, 1077 (1990).

7) Yamaguchi M, Wakutsu, M, Takahashi $Y$ and Noda I, Macromolecules, 25, 470, 475 (1992).

8) Noda I, in "Progress in Pacific Polymer Science 2", Y. Imanishi, Ed., Springer-Verlag, Berlin, p. 301, 1992.

9) Takahashi Y, Hase H, Yamaguchi M and Noda I, J. Non-Crystalline Solids, 172-174, 911 (1994).

10) Takahashi $Y$, Iio $S$, Matsumoto $N$ and Noda $I$, Polym. International, 40, 269 (1996)
11) Noda I and Takahashi Y, Ber. Bunsenges. Phys.Chem., 100, 696 (1996).

12) Takahashi $Y$, Umeda $M$ and Noda I, Macromolecules, 21, 2257 (1988).

13) Kitade S, Takahashi Yand Noda I, Macromolecules, 27, 7397 (1994).

14) 落合健二, 位田めぐみ, 北出愃一, 高橋良彰, 野田一郎, 日本レオロジー学会第 23 年会, 1996 年 5 月.

15) Doi M and Ohta T, J. Chem. Phys., 95, 1242(1991).

16) Takahashi Y, Kurashima N, Noda I and Doi M, J. Rheol., 38, 699 (1994).

17) Takahashi $Y$, Kitade S, Kurashima $N$ and Noda I, Polym. J., 26, 1206 (1994).

18) Takahashi $Y$ and Noda I, ACS Syposium Series, 597, 140 (1995).

19) 市川明博, 井村直友, 北出㥀一, 高橋良彰, 野田一郎, 日本レオロジー学会第 23 年会, 1996 年 5 月.

20) Takahashi $Y$, Suzuki H, Nakagawa $Y$ and Noda I, Macromolecules, 27, 6476 (1988).

21) 北出颤一, 修士論文, 名古屋大学, 1994 .

22) 北出愃一, 落合信雄, 高橋良彰, 野田一郎, Nakatani A, Han C. C, 日本レオロジー学会第 23 年会, 1996 年 5 月. 